\title{
STUDI TINGKAT PENGETAHUAN ANAK USIA SEKOLAH TENTANG MAKANAN SIAP SAJI DI MI AL-ASRIYAH BANJAR PANJI, SIDOARJO
}

\author{
Kusuma Wijaya Ridi Putra ${ }^{1}$ \\ ${ }^{1}$ Akademi Keperawatan Kerta Cendekia Sidoarjo
}

Corresponding: ridiputra@hotmail.com

\begin{abstract}
Abstrak
Introduction. Makanan siap saji adalah jenis makanan yang dikemas, mudah disajikan, praktis, atau diolah dengan cara sederhana. Makanan tersebut umumnya diproduksi oleh industri pengolahan pangan dengan teknologi tinggi dan memberikan berbagai zat aditif untuk mengawetkan dan memberikan cita rasa bagi produk tersebut.Penelitian ini bertujuan untuk mengetahui tingkat pengetahuan anak usia sekolah tentang makanan siap saji di MI Al-Asriyah Banjar Panji Sidoarjo. Methods. Desain dalam penelitian ini adalah deskriptif, penelitian ini bertujuan untuk menggambarkan tingkat pengetahuan anak usia sekolah tentang makanan siap saji di MI Al-Asriyah Banjar Panji Sidoarjo, sampel sebanyak 78 responden diambil dengan tekhnik total sampling. Data diperoleh dengan menggunakan kuesioner tertutup skala ordinal. Setelah data terkumpul selanjutnya dilakukan pengolahan data dengan menggunakan cara editing, coding, dan scoring. Results. Hasil penelitian menunjukkan bahwa tingkat pengetahuan anak usia sekolah tentang makanan siap saji di MI Al-Asriyah Banjar Panji Sidoarjo memiliki tingkat pengetahuan lebih dari setengah sebanyak 43 responden (55\%) berpengetahuan cukup. Discussion. Hal ini didukung oleh faktor dari usia, kelas, pernah mendapatkan informasi dan sumber informasi. Penyuluhan tentang makanan siap saji pada anak usia sekolah sehingga dapat menambah pengetahuan anak tentang makanan siap saji.
\end{abstract}

Keywords: Pengetahuan, makanan siap saji, anak usia sekolah

\section{Pendahuluan}

Ritme kehidupan yang menuntut segala sesuatu serba cepat, waktu terbatas, anak harus pergi sekolah sementara ibu dan bapak harus segera berangkat kerja, sebagai jalan pintas untuk sarapan disediakanlah makanan siap saji yang memakan waktu penyiapan 3 sampai 5 menit. Selain mudah disajikan makanan ini umumnya mempunyai cita rasa yang gurih dan umumnya disukai, terutama oleh anak-anak usia sekolah (Republika, 2003). Penelitian University of Bristol, Inggris ini menunjukkan, anak-anak yang makan lebih banyak chip, keripik, biskuit dan pizza sebelum usia tiga tahun memiliki IQ lebih rendah lima tahun kemudian. Mereka yang mengonsumsi makanan siap saji, IQ-nya bisa lebih rendah lima poin IQ dibandingkan dengan anak-anak diberikan diet sehat dengan buah, sayur dan makanan yang dimasak. Menurut penelitian di Kanada, kebiasaan makanan siap saji dapat menyebabkan pikun lebih dini, seperti diutarakan laman Shine. Selain itu, mengonsumsi makanan siap saji secara rutin juga meningkatkan risiko kerusakan memori otak dan mengancam terjadinya demensia. Lemak jenuh dan tingginya kadar gula yang terkandung dalam makanan siap saji telah ditemukan sebagai biang keladi hilangnya memori itu. Masalah lain yang jadi fenomena dimasyarakat adalah tersedianya berbagai jajanan yang dikemas dapat dipastikan "kaya" zat aditif. Tercatat 13 jenis snack mengandung bahan aditif dalam kandungan yang cukup tinggi (Republika, 2003). Resiko yang muncul karena adanya zat adiktif yang berlebihan seperti MSG dapat menyebabkan gangguan kesehatan seperti kerusakan otak, kelainan hati, trauma, hipertensi, stress, demam tinggi, mempercepat proses penuaan, alergi kulit, mual, muntah, migren, asma, ketidakmampuan belajar, dan depresi. Namun, masalah yang tampak di MI Al-Asriyah Banjar Panji adalah banyak anak usia sekolah tidak peduli dengan makanan yang mereka makan, yang anakanak ini fikirkan hanya cita rasanya yang gurih. Banyaknya makanan siap saji yang dijual disekitar sekolah seperti sosis, mie instan, saos, nugget, dan snake yang menyebabakan anak-anak usia sekolah menjadi lebih menyukai makanan siap saji dari pada makanan yang sehat. Selain itu banyak anak usia sekolah yang tidak mau membawa bekal dari rumah. Bagi ibu yang bekerja di luar rumah, makanan siap saji memberikan keuntungan dan kemudahan dalam penyajian, tanpa memperhatikan kesehatan anaknya.

\section{Metode dan Bahan}

Untuk membahas permasalahan yang ada dalam penelitian ini, maka jenis penelitian ini adalah deskriptif. Penelitian diskriptif adalah suatu metode penelitian yang dilakukan dengan tujuan utama untuk membuat suatu gambaran atau deskriptif tentang suatu keadaan obyektif (Notoatmojo, 2005). Penelitian ini dilakukan di MI Al-Asriyah Banjar Panji Sidoarjo. Waktu dilaksanakan penelitian ini pada November 2016. Populasi pada penelitian ini adalah Anak Usia Sekolah kelas 4-6 di MI Al-Asriyah Banjar Panji Sidoarjo dengan jumlah 78 siswa. Teknik sampling yang digunakan adalah teknik total sampling, sehingga 
seluruh populasi akan dijadikan sebagai responden pada penelitian ini. Instrument yang digunakan dalam pengumpulan data yang dilakukan dalam penelitian ini untuk variabel pengetahuan adalah kuesioner sebanyak 15 pertanyaan yang disebarkan pada responden. Setelah data terkumpul, maka peneliti akan melakukan editing, coding, analisis.

\section{Hasil Penelitian}

Berdasarkan data pada tabel 3.1 didapatkan hasil persentase menurut tingkat pengetahuan responden tentang makanan siap saji yaitu lebih dari sebagian responden mempunyai tingkat pengetahuan cukup yaitu sebanyak $55 \%$ (43 responden).

\section{Pembahasan}

Hasil penelitian tingkat pengetahuan anak usia sekolah tentang makanan siap saji di MI Al-Asriyah Banjar Panji Sidoarjo, ternyata peneliti mendapatkan data bahwa sebagian besar responden mempunyai tingkat pengetahuan cukup sebanyak 55\% (43 responden) dan sebagian kecil responden mempunyai tingkat pengetahuan kurang yaitu sebanyak 18\% (14 responden). Sesuai dengan hasil penelitian di atas dapat diketahui ada beberapa faktor yang mempengaruhi tingkat pengetahuan anak usia sekolah di MI Al-Asriyah Banjar Panji Sidoarjo faktor internal yang terdiri dari : usia, intelegensia, pemahaman, keyakinan, sistem nilai dan keyakinan dan faktor eksternal, terdiri dari: Pendidikan formal dan informal, pergaulan atau lingkungan sosial, sarana informasi (media massa dan elektronuka), sosial, ekonomi, dan budaya, latar belakang pendidikan.

Responden yang usianya semakin tua seharusnya memiliki tingkat pengetahuan yang lebih baik, namun dalam penelitian ini usia yang lebih muda memiliki tingkat pengetahuan cukup dibandingkan dengan responden yang usianya lebih tua, hal tersebut dikarenakan pola pikir seseorang dalam mendapat pengetahuan tidak harus usianya lebih tua, sebab usia yang lebih muda lebih antusias apabila ada pembelajaran tentang makanan siap saji yang dijelaskan oleh gurunya, sehingga tingkat pengetahuannya baik dibandingkan dengan responden yang usianya lebih tua. Menurut Notoatmojo (2005) semakin tua umur seseorang tidak menjamin tingkat pengetahuanya lebih baik dan umur yang mudah tidak menjamin tingkat penetahuannya kurang, hal tersebut dikarenakan daya pikir seseorang berbeda-beda tidak bergantung dari umur.

Semakin tinggi tingkat pendidikan seseorang akan memiliki pengetahuan yang luas tentang makanan siap saji. Seperti yang diungkapkan oleh Alwi Hasan (2004) tidak sesuai dengan kenyataan responden, yaitu pendidikan merupakan proses mengubah sikap dan tata laku seseorang atau kelompok orang dalam usaha mendewasakan manusia melalui upaya pengajaran dan
Tabel 3.1 Distribusi frekuensi berdasarkan tingkat pengetahuan anak usia sekolah tentang makanan siap saji di MI Al-Asriyah Banjar Panji Sidoarjo pada November 2016.

\begin{tabular}{|c|c|c|}
\hline $\begin{array}{c}\text { Tingkat } \\
\text { Pengetahuan }\end{array}$ & $\begin{array}{c}\text { Jumlah } \\
\text { Responden }\end{array}$ & Prosentase \\
\hline Baik & 14 & $18 \%$ \\
\hline Cukup & 43 & $55 \%$ \\
\hline Kurang & 21 & $27 \%$ \\
\hline Jumlah & 78 & $100 \%$ \\
\hline
\end{tabular}

pelatihan. Dan menurut Kontjaraningrat (2004), pendidikan diperlukan untuk mendapatkan informasi, misal hal - hal yang menunjang kesehatan sehingga dapat menigkatkan kualitas hidup, makin tinggi tingkat pendidikan seseorang, makin mudah menerima informasi sehingga makin banyak pula pengetahuan yang dimilikinya, sebaliknya pendidikan yang kurang dan menghambat perkembangan sikap seseorang terhadap nilai - nilai yang baru diperkenalkan.

Responden yang pernah mendapat informasi tentang makanan siap saji seharusnya memiliki tingkat pengetahuan yang lebih baik, karena dengan seringnya responden memperoleh informasi maka responden tersebut akan lebih mengerti dan lebih paham tentang makanan siap saji maka tingkat pengetahuanyapun akan lebih baik. Namun dalam penelitian ini responden yang tiadak pernah mendapat informasi mempunyai persetase tingkat penetahuan yang cukup dibandingkan dengan responden yang sudah mendapat informasi tentang makanan siap saji, hal tersebut terjadi dikarenakan pola pikir seseorang dalam menerima suatu informasi yang berbeda-beda sehingga meskipun responden yang pernah mendapat informasi tentang makanan siap saji tapi pengetahuanya mereka sangat kurang. Menurut Erfandi (2009) pengetahuan itu diperoleh dari proses belajar tetapi juga tergantung pada pengetahuanya masing-masing, sehingga jika seseorang yang sudah mendapat informasi dan tidak mendapat informasi belum tentu berpengaruh terhadap tingkat pengetahuan dan daya pikir seseorang.

Sumber informasi anak usia sekolah lebih banyak didapatkan dari buku karena di sekolah anak lebih banyak waktu untuk membaca buku. Di karenakan dengan membaca buku maka informasi yang didapat oleh siswa akan lebih efektif dan daya serap siswa dengan membaca buku akan lebih baik untuk meningkatkan tingkat pengetahuan tentang makanan siap saji. Seperti yang di ungkapkan oleh Notoatmojo 2004, sumber informasi mempengaruhi pengetahuan, baik dari buku, media maupun orang-orang dalam terkaitanya dengan kelompok manusia memberi kemungkinan untuk dipengaruhi dan mempengaruhi anggota-anggotanya. Dengan demikian seorang siswa akan bergantung pada media cetak khususnya buku 
dikarenakan buku merupakan sumber informasi yang mudah didapat disekolah.

\section{Simpulan}

Berdasarkan hasil penelitian ini maka dapat disimpulkan bahwa lebih dari setengah responden sebanyak 55\% (43 responden) tingkat pengetahuan anak usia sekolah di MI Al-Asriyah Banjar Panji Sidoarjo tentang makanan siap saji adalah cukup.

\section{Saran}

Institusi pendidikan sebagai tempat menempuh ilmu keperawatan diharapkan hasil penelitian ini sebagai masukan untuk tambahan materi tentang makanan siap saji. Dalam penelitian selanjutnya diharapkan penelitian ini dengan mencari faktor - faktor lain yang mungkin mempengaruhi isi dari penelitian ini dan dapat memperluas jumlah responden dan penelitian. Serta memperdalam lagi makanan siap saji sehingga dapat memberikan informasi yang lebih pada anak usia sekolah tentang makanan siap saji. Karena tingkat pengetahuan anak usia sekolah tentang makanan siap saji di MI Al-Asriyah Banjar Panji Sidoarjo cukup maka diharapkan anak usia sekolah lebih memperluas lagi pengetahuan tentang makanan siap saji serta meningkatkan pengetahua tentang makanan siap saji. Dan para anak usia sekolah terutama kelas 4, 5, dan 6 di MI Al-Asriyah Banjar Panji Sidoarjo juga dapat membantu dalam memilih makanan yang baik bagi kesehatan.

\section{Daftar Pustaka}

Alimul H. Aziz. 2013. Riset Keperawatan Dan Tehnik Penulisan Ilmiah. Jakarta: Salemba Medika

Arbor, A. 1997. Food additive can cause severe allergic reactions.

Arikuntao, suharsini. 2006. Prosedur Penelitian Suatu Pendekatan Praktek. Jakarta : PT. Rineka Cipta

Intisari. 2001. Makanan dan minuman kemasan, amankah?.www.indomedia.com/intisari/.

Media Indonesia. 2003. Kemasan makanan. http ://www.media.online.com/.

Media Indonesia. 2003. Kemasan makanan. http ://www.media.online.com/.

Mubarak. 2007. Promosi Kesehatan. Jogjakarta: Graha Ilmu.

Notoatmojo,S.2003. Metodologi Penelitian Kesehatan.Jakarta: Rineka Cipta.

Nursalam. (2004). Konsep dan penerapan metodologi penelitian ilmu keperawatan. Jakarta: Salemba.

Nursalam. (2004). Metodelogi riset keperawatan. Jakarta: Salemba.

Nursalam. (2004). Pendekatan praktis metodelogi riset keperawatan. Jakarta: Salemba.

Nursalam, (2004). Konsep Dan Penerapan Metodologi Penelitian Ilmu keperawatan, Salemba Medika, Jakarta.

Nursalam dan Pariani, Siti. 2001. Pendekata Praktis
Metodologi Riset Keperawatan, Infomedika : Jakarta.

Republika. 2003. Pirac: 13 jenis snack mengandung MSG yang bisa ancam kesehatan anak.

Wahid iqbal. 2007.Promosi Kesehatan. Jogjakarta: Graha Ilmu 